\title{
Distribution of the American grapevine leafhopper (Scaphoideus titanus ball 1932) in west Romania
}

\author{
Tímea Szalárdi - Károly Nagy - Antal Nagy \\ University of Debrecen, Institute of Plant Protection, 4032 Debrecen, Böszörményi út 138. \\ szalardi@agr.unideb.hu
}

\begin{abstract}
SUMMARY
The vector of Grapevine Flavescens Dorée phytoplasma, the American grapevine leafhopper (Scaphoideus titanus) has been in Europe since 1924. In Romania, the first populations were detected in 2009 in the central, eastern and southern part of the country. Later, the leafhopper was found also in West Romania in 2014. In 2015 and 2017, altogether, 14 sampling sites were studied in two vine regions of this area. The Scaphoideus titanus could be detected in 10 of them with relatively small abundances. During the studies, the yellow sticky traps proved more effective methods than sweep netting. To prevent vineyards from disease, we should do everything against the vector from prevention to chemical protection.
\end{abstract}

Keywords: Grapevine Flavescence dorée phytoplasma, 'Ca. Phytoplasma vitis', american grapevine leafhopper, Scaphoideus titanus, vector, invasive pest

\section{INTRODUCTION}

The American grapevine leafhopper (Scaphoideus titanus) (Figure 1) has been introduced from North America to Europe in 1920's. First time it was found in France in 1924 (Daire et al., 1997). Recently the species distributed in larger part of the continent and causes significant damage in vineyards with spreading a phytoplasma ( $\mathrm{Ca}$. Phytoplasma vitis) which is a causal agent of Grapevine Flavescence dorée (Riolo et al., 2014).

In Europe Scaphoideus titanus feeds only on grape, but in North America it can be found also on Rumex, Salix, Crataegus and Fraxinus species (Mori et al., 2002). The leafhopper feeds on the lower surface of leaves.

In an average transmission trial, the mean acquisition access period is 4-8 days, and it is followed by a $4-5$-weeks latent period. Considering the life cycle of the pest the larvae of $4^{\text {th }}$ and $5^{\text {th }}$ instars and imagoes can transmit disease (Caudwell et al., 1970). These insects keep their infection ability during their whole life (Lefol et al., 1993). The transmission of the phytoplasma can be started one month after the first individuals hatching from eggs. Larvae hatch from eggs during May and first half of June, and imagoes appear in July. The pest has one generation per year. The larvae and imagoes are both vectors of the phytoplasma. The external symptoms will appear on the plant only next summer, thus the ratio of the plants expressing external symptoms can not provide real picture about the real infection rate of the given vineyard (Szalárdi et al., 2015).

The Romanian distribution of the species was published in 2011. Between 2009 and 2011 Chireceanu and co-workers (2011) studied different wine regions and found large populations in surroundings of Bucharest, Balászfalva (Blaj) (in Transylvania), Murfatlar (Dobrudja) and Banu Maracine (Oltenia). The studied populations showed increasing abundances especially in the abandoned vineyards. The first record of Scaphoideus titanus from West Romania (Micske, Bihor county) was published in 2014, when East Hungarian distribution was also studied in Hajdú-Bihar county (Szalárdi et al., 2014).

Figure 1: American grapevine leafhopper (Scaphoideus titanus) imago caught by yellow sticky trap in 2015

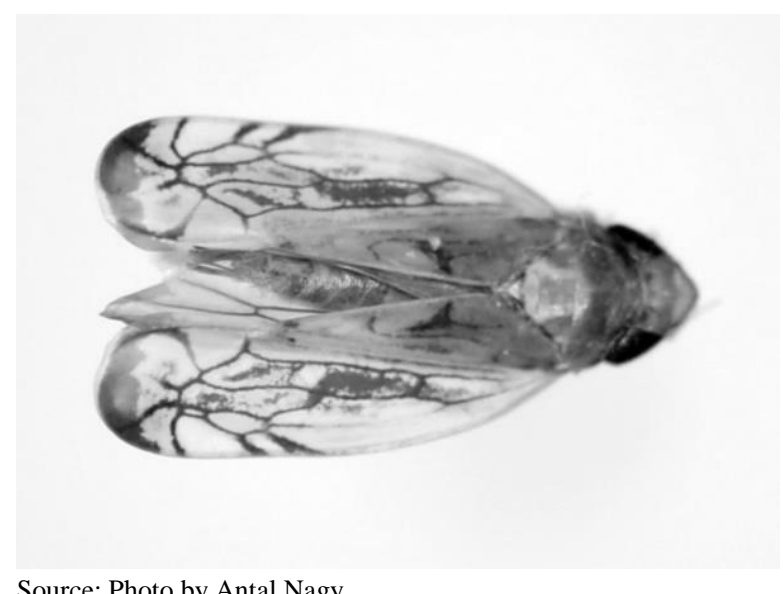

Source: Photo by Antal Nagy

After the first detection of the west Romanian distribution in 2015 and 2017 more extensive samplings were made in different West Romanian sites along the Hungarian border.

\section{MATERIALS AND METHODS}

In 2015 and 2017 different parts of the Érmellék (Crisana) and the Arad (Minis) vine region were studied. The Érmellék Vine region traditionally situated on the borders of Bihar (Bihor), Szatmár (Satu Mare) and Szilágy (Salaj) counties but their main part can be found between Nagyvárad (Oradea) and Szatmárnémeti (Satu Mare). The Arad vine region is in the surroundings Arad in Arad county. In 
Érmellék 12 near 9 villages while in Arad 2 sampling sites were studied in boundary of one village. In 2015 10 mostly extensively used vineyards and in 20174 sampling sites mostly in intensively cultivated vineyards were studied (Figure 2, Table 1).

Samplings was focused to catching imagoes in late summer and early autumn (Table 2). In 2015 sampling was made with both sweep net and yellow sticky traps, while in 2017 we used only sticky traps. There were one A4 size sticky traps at each site. In case of netting insects collected from the leaves were capture with aspirator and then was preserved and stored in 70 $\mathrm{V} / \mathrm{V} \%$ ethanol. As the other method yellow sticky traps (CSALOMON $\left.{ }^{\circledR}\right)$ were used. They were fixed on the trellis work, in the foliage of the plant in 1-1.5 meter height.

In 2015 the number of individuals was determined by sexes while in 2017 only the total number of sampled individuals were count on the yellow sticky traps.

Figure 2: Sampling sites of the american grapevine leafhopper (Scaphoideus titanus) studied in 2015 and 2017 in West Romania (see also Table 1)

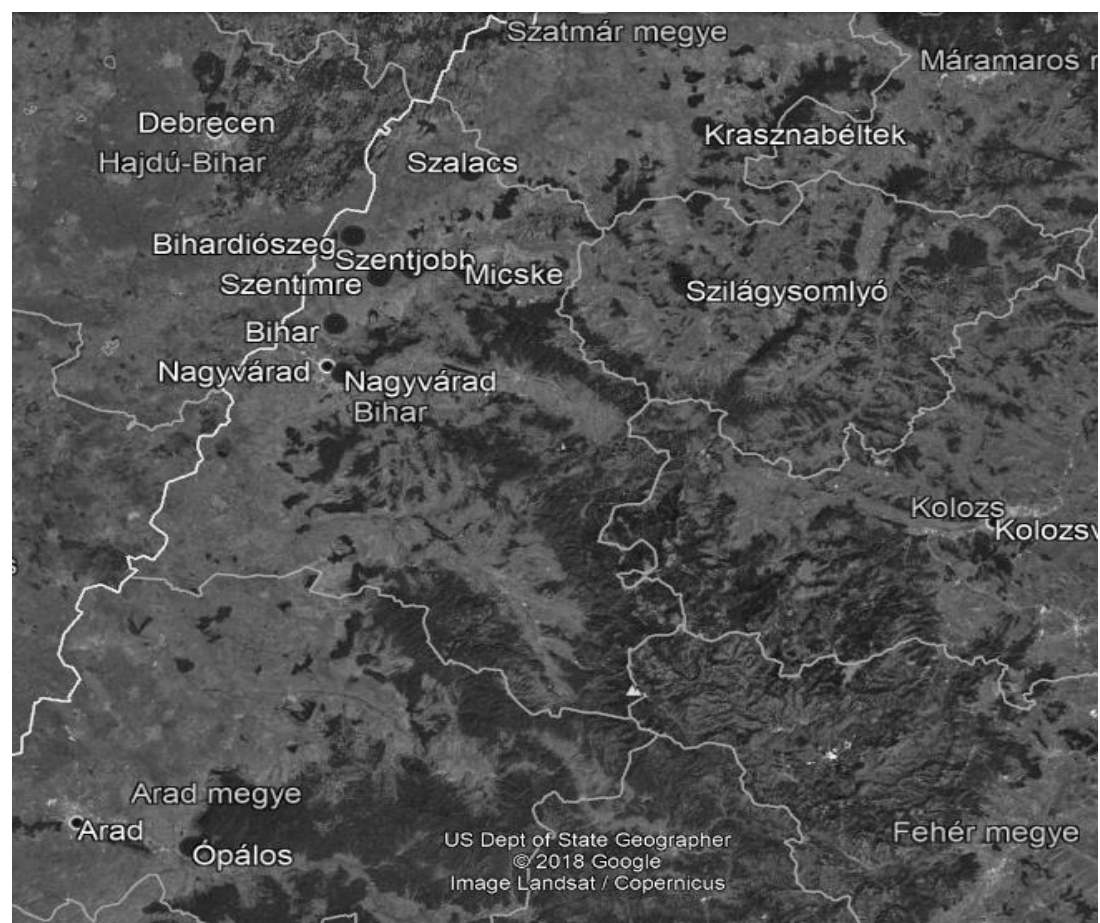

Source: GoogleEarth 2018

Table 1

Sampling sites of the American grapevine leafhopper (Scaphoideus titanus) studied in 2015 and 2017 in West Romania (see also Figure 1) with coordinates and short description of sites and used sampling methods. S: sweep netting, YST: yellow sticky trap

\begin{tabular}{|c|c|c|c|c|c|}
\hline & Sampling site & GPS: N & GPS: E & $\begin{array}{l}\text { Sampling } \\
\text { method }\end{array}$ & Characterisation of sites \\
\hline \multirow{10}{*}{$\stackrel{n}{\text { ñ }}$} & Bihar (Bihor) & $47^{\circ} 9^{\prime} 2.73^{\prime \prime}$ & $21^{\circ} 56^{\prime} 57.84^{\prime \prime}$ & $\mathrm{S}$ & extensive sparse vineyards in the boundary of the village \\
\hline & Diószeg (Dioshig) & $47^{\circ} 17^{\prime} 13.91^{\prime \prime}$ & $22^{\circ} 0 ' 24.34^{\prime \prime}$ & $\mathrm{S}$ & extensive sparse vineyards in the boundary of the village \\
\hline & Micske (Misca) & $47^{\circ} 16 ' 2.31^{\prime \prime}$ & $22^{\circ} 15^{\prime} 39.05^{\prime \prime}$ & S, YST & grape trellis in the village, not managed \\
\hline & Nagyvárad (Oradea) & $47^{\circ} 5^{\prime} 10.15^{\prime \prime}$ & $21^{\circ} 56^{\prime} 43.67^{\prime \prime}$ & $\mathrm{S}$ & extensive sparse vineyards in the boundary of the village \\
\hline & Szalacs (Salacea) 1. & $47^{\circ} 27^{\prime} 7.71^{\prime \prime}$ & $22^{\circ} 16^{\prime} 39.90^{\prime \prime}$ & $\mathrm{S}$ & extensive sparse vineyards in the boundary of the village \\
\hline & Szalacs (Salacea) 2. & $47^{\circ} 27^{\prime} 7.38^{\prime \prime}$ & $22^{\circ} 16^{\prime} 27.21^{\prime \prime}$ & S & extensive sparse vineyards in the boundary of the village \\
\hline & Szentimre (Santimreu) 1. & $47^{\circ} 15^{\prime} 12.50^{\prime \prime}$ & $22^{\circ} 3^{\prime} 58.80^{\prime \prime}$ & S, YST & extensive sparse vineyards in the boundary of the village \\
\hline & Szentimre (Santimreu) 2. & $47^{\circ} 15^{\prime} 20.92^{\prime \prime}$ & $22^{\circ} 3^{\prime} 50.82^{\prime \prime}$ & S, YST & extensive sparse vineyards in the boundary of the village \\
\hline & Szentjobb (Saniob) 1. & $47^{\circ} 15^{\prime} 59.80^{\prime \prime}$ & $22^{\circ} 7^{\prime} 19.13^{\prime \prime}$ & S, YST & larger plantation in the boundary of the village, managed \\
\hline & Szentjobb (Saniob) 2. & $47^{\circ} 16^{\prime} 29.66^{\prime \prime}$ & $22^{\circ} 7^{\prime} 59.77^{\prime \prime}$ & $\mathrm{S}$ & larger plantation in the boundary of the village, managed \\
\hline \multirow{4}{*}{$\frac{\sqrt{2}}{\grave{\delta}}$} & $\begin{array}{c}\text { Szilágysomlyó (Simleu } \\
\text { Silvaniei) }\end{array}$ & $47^{\circ} 14^{\prime} 1.20^{\prime \prime}$ & $22^{\circ} 48^{\prime} 54.41^{\prime \prime}$ & YST & grape trellis in the village, slightly managed \\
\hline & Krasznabéltek (Beltiug) & $47^{\circ} 32^{\prime} 56.71^{\prime \prime}$ & $22^{\circ} 51^{\prime} 35.14^{\prime \prime}$ & YST & intensive large vineyard in the boundary of the village \\
\hline & Ópálos (Paulis) 1 & $46^{\circ} 7^{\prime} 22.49^{\prime \prime}$ & $21^{\circ} 36^{\prime} 2.48^{\prime \prime}$ & YST & intensive large vineyard in the boundary of the village \\
\hline & Ópálos (Paulis) 2 & $46^{\circ} 7^{\prime} 20.76^{\prime \prime}$ & $46^{\circ} 7^{\prime} 20.76^{\prime \prime}$ & YST & intensive large vineyard in the boundary of the village \\
\hline
\end{tabular}




\section{RESULTS AND DISCUSSION}

During preliminary samplings in June of 2015 the leafhoppers could not be captured by netting, but in August and September we caught 1-2 specimens near Micske, Szalacs and Bihar villages. The yellow sticky traps were more effective for imago sampling. We can detect the species in all 4 sites sampled with this method (Szentjobb, Szentimre, Micske). Although sticky traps showed the occurrence of the pest both in Szentjobb 1 and Szentimre 1 and 2 sites, but we could not catch it with netting. This also proved the highest efficiency of trapping method. The netting may be effective with increased sampling effort. Population lives in Micske showed the larger abundance while in Szentimre only one individual was caught (Table 2). These abundances were much lower than that we measure in Micske and especially in nearly East Hungarian sites in the former (2014) and next (2016) year (Szalárdi et al., 2014, 2016).

In 2017 we detected the occurrence of Scaphideus titanus in all sampled sites, but the abundances were again relatively low.

Number of collected Scaphoideus titanus individuals in 2015 and 2017 in West Romanian sites with sweep netting and yellow sticky traps

\begin{tabular}{|c|c|c|c|c|c|c|c|c|c|}
\hline & \multirow[t]{2}{*}{ Sampling sites } & \multicolumn{4}{|c|}{ Sweep netting } & \multicolumn{4}{|c|}{ Yellow sticky traps } \\
\hline & & date & male & female & total & date & male & female & total \\
\hline \multirow{14}{*}{$\frac{n}{\ddot{n}}$} & Szentjobb (Saniob) 1. & 27 June & 0 & 0 & 0 & 20 Aug.-9 Sept. & 3 & 2 & 5 \\
\hline & & 1 October & 0 & 0 & 0 & & & & \\
\hline & Szentjobb (Saniob) 2. & 18 Aug. & 0 & 0 & 0 & & & & \\
\hline & Szentimre (Santimreu) 1. & 27 June & 0 & 0 & 0 & 20 Aug.-9 Sept. & 1 & 0 & 1 \\
\hline & & 18 Aug. & 0 & 0 & 0 & & & & \\
\hline & Szentimre (Santimreu) 2. & 27 June & 0 & 0 & 0 & 20 Aug.-9 Sept. & 3 & 3 & 6 \\
\hline & & 18 Aug. & 0 & 0 & 0 & & & & \\
\hline & Micske (Misca) & 27 June & 0 & 0 & 0 & 20 Aug.-9 Sept. & 6 & 8 & 14 \\
\hline & & 25 Aug. & 1 & 0 & 1 & & & & \\
\hline & Szalacs (Salacea) 1. & 26 Aug. & 0 & 0 & 0 & & & & \\
\hline & Szalacs (Salacea) 2. & 26 Aug. & 2 & 0 & 2 & & & & \\
\hline & Bihardiószeg (Dioshig) & 2 Sept. & 0 & 0 & 0 & & & & \\
\hline & Bihar (Bihor) & 2 Sept. & 1 & 0 & 1 & & & & \\
\hline & Nagyvárad (Oradea) & 3 Sept. & 0 & 0 & 0 & & & & \\
\hline \multirow{3}{*}{$\stackrel{5}{\check{c}}$} & Krasznabéltek (Beltiug) & & & & & 1 Sept.-3 October & - & - & 3 \\
\hline & $\begin{array}{c}\text { Szilágysomlyó (Simleu } \\
\text { Silvaniei) }\end{array}$ & & & & & 1 Sept.-3 October & - & - & 12 \\
\hline & Ópálos (Paulis) & & & & & 1 Sept.-3 October & - & - & 22 \\
\hline
\end{tabular}

According to our results Scaphoideus titanus is widely distributed in West Romania along the Hungarian border as it distributed also in the Hungarian side (Szalárdi et al., 2014; 2016). The sampled habitats are mainly extensively managed vineyards, but the intensive plantations were also infected in Ópálos (Arad county).

The only method of protection against the phytoplasma (Grapevine Flavescence dorée) is protecting against the vector Scaphoideus titanus. The lack of detailed knowledge and the landscape structure with sparse extensively managed or abandoned vineyards make the plant protection against the vector and the disease nearly impossible. Notwithstanding these difficulties we should try to inform the owners and growers of this risk and if it is necessary, we should act against the vector.

\section{AKNOWLEDGEMENT}

Authors thank vineyard owners for providing a free run of our study on their vineyards.

\section{REFERENCES}

Caudwell, A--Kuszala, C.-Bachelier, J. C--Larrue, J. (1970): Transmission de la Flavescence dorée de la vigne aux herbacées par l'allongement du temps d'utilisation de la cicadelle Scaphoideus littoralis Ball et l'étude de sa survie sur un grand nombre d'espèces végétales. Annales de Phytopathologie 2: 415-428.

Chireceanu, C.-Ploaie, P. G.-Gutue, M.-Nicolae, I.-Stan, C.Comsa, M. (2011): Detection of the Auchenorrhyncha Fauna
Associated with grapevine Displaying Yellows Symtoms in Romania, Acta Phytopatologica et Entomologica Hungarica 46: 253-260.

Daire, X.-Clair, D.-Larrue, J.-Boudon-Padieu, E. (1997): Survey for grapevine yellows in diverse European countries and Israel. Vitis 36: 53-54.

Lefol, C.-Lherminier, J.-Boudon-Padieu, E.-Larrue, J.-Louis, C.Caudwell, A. (1994): Propagation of the Flavescence dorée My 
coplasm organism in the leafhopper vector Euscelidius variegatus Kbm. J. Invert. Pathol. 63:pp. 285-293.

Mori, N.-Bressan, A.-Martini, M.-Guadagnini, M.-Girolami, V Bertaccini A. (2002): Experimental transmission by Scaphoideus titanus ball of two Flavescence dorée-type phytoplasmas. Vitis. 41: 99-102.

Riolo, P.-Minuz, R. L.-Landi, L.-Nardi, S.-Ricci, S.-Righi, M.Isidoro, N. (2014): Population dynamics and dispersal of Scaphoideus titanus from recently recorded infested areas in central-eastern Italy. Bulletin of Insectology 67(1): 99-107.
Szalárdi, T.-Nagy, A.-Tarcali, G. (2014): Az amerikai szőlőkabóca (Scaphoideus titanus Ball) előfordulásának vizsgálata Debrecenben és a Nyugat-romániai Micskén. Agrártudományi Közlemények - Acta Agraria Dedreceniensis 62: 77-81.

Szalárdi, T.-Tarcali, G.-Nagy, K.-Szarukán, I.-Nagy, A. (2015): Az aranyszínű sárgaság fitoplazma és az amerikai szőlőkabóca elterjedése Magyarországon 2014-ben 